\title{
Evaluation of ColdZyme Mouth Spray for the Protection against Common Cold in Elite Athletes to Reduce Unwanted Absence from Training and Competition
}

\author{
Mats Clarsund \\ Enzymatica AB, Lund, Sweden \\ Email: mats.clarsund@enzymatica.com
}

How to cite this paper: Clarsund, $M$. (2017) Evaluation of ColdZyme Mouth Spray for the Protection against Common Cold in Elite Athletes to Reduce Unwanted Absence from Training and Competition. Open Journal of Respiratory Diseases, 7, 103-109. https://doi.org/10.4236/ojrd.2017.73010

Received: May 10, 2017

Accepted: June 16, 2017

Published: June 19, 2017

Copyright $\odot 2017$ by author and Scientific Research Publishing Inc. This work is licensed under the Creative Commons Attribution International License (CC BY 4.0).

http://creativecommons.org/licenses/by/4.0/

\begin{abstract}
This study evaluated the protective effect of ColdZyme on common cold infections in elite athletes from three different sports (biathlon, ice-hockey and handball), and assessed the level of reduction in corresponding sick days. The biathlon team $(n=11)$ and the ice-hockey team $(n=29)$ significantly reduced the average number of sick days by $51 \%$ respectively $67 \%$ compared to historical data. No historical data on sick days was available for the handball team but $76 \%$ of those who experiences a cold during the study period reported little or very little impact on training and competition. Conclusion: Using ColdZyme may be an easy and practical way for elite athletes to protect themselves against the common cold and to prevent corresponding unwanted absence from training and competition.
\end{abstract}

\section{Keywords}

Common Cold, Athletes, ColdZyme ${ }^{\circledast}$ Mouth Spray

\section{Introduction}

The protection of common cold infection is particularly important for athletes during prolonged periods of heavy training due to the potential negative influence on performance. Repeated periods of infection are linked to recurrent physical injuries that can be detrimental for the athlete and the team [1]. A few studies suggest that elite athletes suffer from more upper respiratory tract infections than recreational athletes [2] [3]. Data on the relationship between training and competition load and the risk of illness are limited to a few selected sports and athlete populations and high loads have been reported to have either posi- 
tive or negative influences on risk of illness in athletes [1] [4]. There is a wellestablished association between prolonged hard exercise and suppressed immune function resulting in transient depression of white blood cell functions [4]. It is suggested that such changes create an "open window" of decreased host protection, during which viruses can gain a foothold, increasing the risk of developing an infection [5]. According to Gleeson [6] the post-exercise immune function decrease is most pronounced when the exercise is continuous, prolonged ( $>1.5 \mathrm{~h}$ ), of moderate to high intensity ( $55 \%-75 \%$ of aerobic capacity) and performed without food intake. Upper respiratory tract infections such as common cold is one of the main reason for missed training among UK elite athletes in 30 different Olympic sports and common cold has been reported to be the most common medical condition affecting athletes at both the summer and winter Olympic Games [7]. According to the International Olympic Committee consensus statement on load in sport and risk of illness it is estimated that about $50 \%$ of all acute illness in athletes during competitions and tournaments affect the respiratory tract [1]. In conclusion, the specific conditions for elite athletes, such as hard exercise and travelling, are conducive for being infected by common cold viruses [3] [8].

A wide range of cold remedies is sold on prescription and over-the-counter, but systematic reviews conclude that there is still no reliable prevention or cure available, and the potential serious side effects of popular pharmacologically acting products also should be considered [9]. A few studies suggest that probiotic intake can enhance resistance to upper respiratory tract infections in athletes and e.g. reference [10] found that endurance athletes on a probiotic reported less than half the number of days of respiratory symptoms compared to those on placebo.

Epithelial cell layers in oral and nasal cavities form a physical and innate immune barrier against bacteria and viruses [11]. Yet, viruses can infect the mucosal cells in this area resulting in cold symptoms. To prevent infection, the natural barrier can be strengthened by depositing a barrier to the oropharyngeal mucous membrane. ColdZyme ${ }^{\varpi}$ Mouth Spray (Coldzyme) is a medical device against common cold. It is designed to deposit a viscous solution containing primarily glycerol and trypsin to the mouth/throat, thereby, reducing the probability of catching a cold and to help shorten duration of a cold by forming a thin protective barrier on the oropharyngeal mucous membrane. ColdZyme was shown to be efficacious in a clinical study, in which the viral load decreased significantly $(p=0.02)$ and the number of days for one episode with common cold symptoms was reduced from 6.5 to 3 days, in comparison to placebo [12].

The objective in this study was to evaluate whether ColdZyme ${ }^{\oplus}$ Mouth Spray (Enzymatica AB, Lund, Sweden) could be used by elite athletes to protect themselves against the common cold and corresponding unwanted absence from training and competition. This is the first report of this kind in the literature.

\section{Methods}

ColdZyme is a mouth spray containing a solution based on glycerol, buffer, a 
flavouring agent and a psychrophilic cod trypsin. Three prospective, open-label, observational product evaluation studies by three elite athlete teams were conducted during the cold season (August to March) in Sweden from 2009 to 2014 to evaluate the effect of ColdZyme to reduce number of sick-days (primary outcome parameter). A biathlon team $(\mathrm{n}=11)$ competing on national and international level used ColdZyme during three months (January 2012 to March 2012). An ice-hockey team $(n=29)$ in the second-highest league in Sweden used ColdZyme during 12 months from August 2010 to March 2011 and from August 2011 to December 2011 and finally, a handball team $(n=20)$ playing in the highest league in Sweden used ColdZyme during 6 months from September 2013 to February 2014. The ice-hockey team consisted of different players between the seasons and the average number of players in the team was 29. No power calculation to determine sample sizes were done. All athletes in each team were included in each study and no other selection criteria were used. According to the local ethics committee, a formal approval from the committee is not necessary for these product evaluation studies. The studies were designed to be as real-life as possible i.e. the instructions how to use ColdZyme were therefore identical to the instructions for use in the insert to the product. For prevention, it is recommended to spray one dose every second hour when believed being exposed to cold virus e.g. when travelling to competitions and to obtain shortening of the duration of a cold it is recommended to start to spray one dose every second hour as soon as possible after noticing symptoms of a cold and continue until the symptoms are relieved. Compliance in terms of number of doses taken was not recorded or controlled. To reduce potential bias, reported sick-days (i.e. absence from training and competition) were used to evaluate the effect of ColdZyme instead of using subjective symptoms related to common cold. All athletes in the biathlon team answered a quality of life questionnaire after the study period. The questionnaire contained the following questions: 1) How did you experience your quality of life when you used ColdZyme compared to previous seasons (Much better, Better, Same, Worse, Much worse); 2) If you had a cold how did you experience the cold(s) in this study compared with previous colds (Much milder, Milder, Same, Worse, Much worse). Those handball players who experienced a cold were also asked to fill in an evaluation form containing quality of life questions after the study period. This questionnaire contained the following questions: 1) If you had a cold how did you experience the cold(s) in this study compared with previous colds (Much milder, Milder, A little milder, Same, A bit worse, Worse, Much worse); 2) How did the cold affect your ability to work, perform at peak levels, sleep, live your ordinary life (Not at all, Very little, Little, Some, A lot). No questionnaire was given to the ice-hockey team. A procedure for reporting adverse events for all athletes was established. Participation in the studies was voluntary and athletes were free to withdraw their consent at any time.

All distribution of product, collection of questionnaire and documentation of sick days, absence from training and competition were done by each team coach. Historical data for the biathlon team were taken from each athletes training di- 
ary. Statistical hypothesis for the analysis of average number of sick days in the biathlon team were analyzed using paired, two-tailed Student's t test with a significance level of $5 \%$ and the average number of sick days per month in the ice-hockey team were analyzed using unpaired, two tailed Student's t test with a significance level of $5 \%$.

\section{Findings}

In total, 57 male athletes and 3 female athletes (all in the biathlon team) were included and all completed their respectively study without any reported adverse events. The average number of absence days decreased significantly for the biathlon and ice-hockey team when using ColdZyme compared to a corresponding control period (Table 1). The average number of common cold related sick days decreased from 7.0 to 3.5 days for the biathlon athletes $(p=0.04)$, Table 1 , corresponding to a decrease in average number of sick days from 2.4 to 1.2 days per month. The ice-hockey team evaluated ColdZyme during 1.5 seasons i.e. during 12 months and compared number of sick days to a period of 9 months when not using ColdZyme. In total 45 sick days (0.17 days per athlete and month) were registered for the control period and 20 sick days ( 0.057 days per athlete and month) for the ColdZyme period. The average number of sick days per month decreased by $67 \%$ (from 0.17 to $0.057, p=0.02$ ), Table 1 .

The biathlon athletes had complete training diaries for several previous winter seasons and the average numbers of registered sick days due to common cold for all subjects during January to March are shown in Figure 1. It is evident that some athletes are more prone to become ill. For the historical (control) periods when not using ColdZyme, subject \#1 had on average 17 sick days and subject \#9 had 10 days compared to subject \#10 who had zero days. Subject \#1 and \#9 reduced their number of sick days and corresponding absence from training and competition by 70 respective 81 percent when using ColdZyme. No effect was observed among those subjects who historically reported few sick days (i.e. $\leq 2$ sick days). All biathlon athletes also completed a quality of life assessment questionnaire and to the question "How did you experience the cold(s) in this study compared with previous colds?", 9 out of 11 athletes reported the cold to be milder or much milder than previous colds. To the question "How did you experience your quality of life when you used ColdZyme compared to previous seasons?", 9 of 11 athletes reported that they had felt better or much better the last season compared to earlier seasons.

Table 1. Missed training and competition days due to common cold.

\begin{tabular}{cccccc}
\hline Athlete team & Measure & Control & ColdZyme & $\begin{array}{c}\text { Difference } \\
(\%)\end{array}$ & $p$ \\
\hline Biathlon $(\mathrm{n}=11)$ & $\begin{array}{c}\text { Average sick days per } \\
\text { period (per month) }\end{array}$ & $7.0(2.35)$ & $3.5(1.15)$ & -51 & $0.04^{\mathrm{a}}$ \\
Ice-hockey $(\mathrm{n}=29)$ & Average sick days per month & 0.17 & 0.06 & -67 & $0.02^{\mathrm{b}}$ \\
Handball $(\mathrm{n}=20)$ & Average sick days per month & - & 0.12 & - & - \\
\hline
\end{tabular}

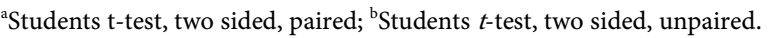




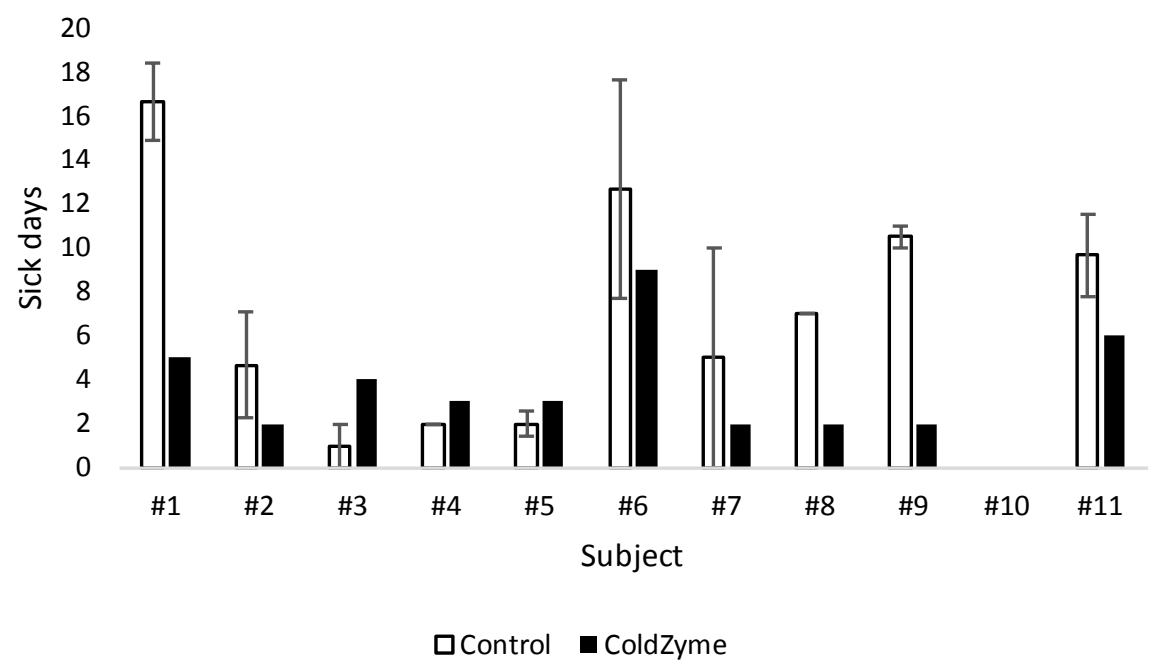

Figure 1. Training diary registered sick days due to common cold for each athlete in the biathlon team from January to March for the control period (average based on reported sick days for year 2009, 2010 and 2011) compared to the period when using ColdZyme (January to March, 2012).

The handball athletes reported on average 0.12 sick days per month when using ColdZyme, and those handball athletes who experience a cold $(\mathrm{n}=8)$ completed a questionnaire about quality of life like aspects. To the question "How did you experience the cold(s) in this study compared with previous colds?", $75 \%$ reported the cold to be milder than previous colds and $25 \%$ reported it to be similar. To the question "How did the cold affect your ability to compete/train, perform at peak level, sleep and live your ordinary life, 76\% reported little or very little impact and $24 \%$ reported some impact.

\section{Discussion}

These studies show that use of ColdZyme by elite athletes can significantly reduce absence from training and competition caused by common cold infections. Athletes might have an increased risk of being infected during the post-exercise immune function depression after prolonged training. There are several recommended guidelines for athletes how to limit the risk of infection and to limit transmission of infections among athletes, which is of importance for team athletes. General recommendations are e.g. to avoid crowded areas, infected persons, to isolate infected team member, get adequate sleep, nutrition [7].

The reduction in sick days due to common cold and corresponding reduction in absence from training by $>50 \%$ for the athletes in this study reflects previous findings from a double-blind, placebo-controlled study, where subjects treated with ColdZyme displayed significantly decreased viral load and fewer days with common cold symptoms [12]. The susceptibility to infection seems to be individual. Biathlon athletes who historically had less than 2 sick days during January to March do not seem to be easily infected by common cold virus or to develop enough symptoms upon an infection rendering them to miss training or competition. However, those individuals that historically reported more than 
two sick days seemed to benefit more from using ColdZyme (Figure 1). Only two handball players missed one match each due to common cold during the 6-month study period. No comparison to previous season was done, however according to the coach a substantially lower absence due to common cold was observed when using ColdZyme (personal communication).

These observational studies allow the assessment of benefit in real-life settings, but due to the open label un-blinded design without placebo, no assessment of compliance, they are more exposed to bias and the results should therefore be considered as preliminary. Coldzyme is a medical device against common cold. It is designed to deposit a viscous solution containing primarily glycerol and trypsin to the mouth/throat to reduce the probability of catching a cold and to help shorten duration of a cold. The outcome parameter used in this study, reduction in sick days, does not evaluate the direct effect of ColdZyme on common cold symptoms per se but the consequences of having a cold i.e. sick days and missed training/competition days.

In summary, the presented data validates the practical everyday use of ColdZyme in reducing the probability of infection or helping to shorten disease duration, if used at an early stage, of a naturally acquired common cold among elite athletes.

\section{Conclusion}

These prospective, open-label, observational product evaluation studies by elite athlete teams show that use of ColdZyme against common cold reduced number of sick days by $>50 \%$. Using ColdZyme may be an easy and practical way for elite athletes to protect themselves against the common cold and to prevent corresponding unwanted absence from training and competition.

\section{References}

[1] Schwellnus, M., Soligard, T., Alonso, J.M., Bahr, R., Clarsen, B., Dijkstra, H.P., Gabbett, T.J., Gleeson, M., Hägglund, M., Hutchinson, M.R. and van Rensburg, C.J. (2016) How Much Is Too Much? (Part 2) International Olympic Committee Consensus Statement on Load in Sport and Risk of Illness. British Journal of Sports Medicine, 50, 1043-1052.https://doi.org/10.1136/bjsports-2016-096572

[2] Spence, L., Brown, W.J., Pyne, D.B., Nissen, M.D., Sloots, T.P., McCormack, J.G., Locke, A.S. and Fricker, P.A. (2007) Incidence, Etiology, and Symptomatology of Upper Respiratory Illness in Elite Athletes. Medicine and Science in Sports and EXercise, 39, 577. https://doi.org/10.1249/mss.0b013e31802e851a

[3] Gleeson, M. and Pyne, D.B. (2016) Respiratory Inflammation and Infections in High-Performance Athletes. Immunology and Cell Biology, 94, 124-131. https://doi.org/10.1038/icb.2015.100

[4] Walsh, N.P. and Oliver, S.J. (2016) Exercise, Immune Function and Respiratory Infection: An Update on the Influence of Training and Environmental Stress. Immunology and Cell Biology, 94, 132-139. https://doi.org/10.1038/icb.2015.99

[5] Nieman, D.C. (1994) Exercise, Infection, and Immunity. International Journal of Sports Medicine, 15, 131-141. https://doi.org/10.1055/s-2007-1021128

[6] Gleeson, M. (2007) Immune Function in Sport and Exercise. Journal of Applied 
Physiology, 103, 693-699. https://doi.org/10.1152/japplphysiol.00008.2007

[7] Alonso, J.M., Edouard, P., Fischetto, G., Adams, B., Depiesse, F. and Mountjoy, M. (2012) Determination of Future Prevention Strategies in Elite Track and Field: Analysis of Daegu 2011 IAAF Championships Injuries and Illnesses Surveillance. British Journal of Sports Medicine, 46, 505-514. https://doi.org/10.1136/bjsports-2012-091008

[8] Kemmerer, T.P., Cetron, M., Harper, L. and Kozarsky, P.E. (1998) Health Problems of Corporate Travelers: Risk Factors and Management. Journal of Travel Medicine, 5, 184-187. https://doi.org/10.1111/j.1708-8305.1998.tb00504.x

[9] Arroll, B. (2011) Common Cold. BMJ Publishing Group, Hoboken.

[10] Cox, A.J., Pyne, D.B., Saunders, P.U. and Fricker, P.A. (2010) Oral Administration of the Probiotic Lactobacillus Fermentum VRI-003 and Mucosal Immunity in Endurance Athletes. British Journal of Sports Medicine, 44, 222-226. https://doi.org/10.1136/bjsm.2007.044628

[11] Vareille, M., Kieninger, E. and Edwards, M.R. (2011) The Airway Epithelium: Soldier in the Fight against Respiratory Viruses. Clinical Microbiology Reviews, 24 210-229. https://doi.org/10.1128/CMR.00014-10

[12] Clarsund, M., Fornbacke, M., Uller, L. and Ahlström Emanuelsson, C. (2014) Common Cold Prophylaxis Using ColdZyme Mouth Spray. XXXII Congress of the Nordic Association of Otolaryngology, Denmark, 22-24 May 2014, 118.

\section{Submit or recommend next manuscript to SCIRP and we will provide best service for you:}

Accepting pre-submission inquiries through Email, Facebook, LinkedIn, Twitter, etc. A wide selection of journals (inclusive of 9 subjects, more than 200 journals)

Providing 24-hour high-quality service

User-friendly online submission system

Fair and swift peer-review system

Efficient typesetting and proofreading procedure

Display of the result of downloads and visits, as well as the number of cited articles

Maximum dissemination of your research work

Submit your manuscript at: http://papersubmission.scirp.org/

Or contact ojrd@scirp.org 